\title{
Intraventricular Placement of a Spring Expander Does Not Attenuate Cardiac Atrophy of the Healthy Heart Induced by Unloading via Heterotopic Heart Transplantation
}

\author{
M. POKORNÝ ${ }^{1}$, I. MRÁZOVÁ ${ }^{2,3}$, H. KUBÁTOVÁ ${ }^{2}$, J. PIŤHA ${ }^{2}$, J. MALÝ ${ }^{1}$, J. PIRK ${ }^{1}$, \\ H. MAXOVÁ ${ }^{3}$, V. MELENOVSKÝ ${ }^{4}$, J. ŠCHMAN ${ }^{4}$, J. SADOWSKI ${ }^{5}$, L. ČERVENKA ${ }^{2,3}$, \\ Z. ČERMÁK ${ }^{6}$, K. VOLENEC ${ }^{6}$, I. NETUKA ${ }^{1}$ \\ ${ }^{1}$ Department of Cardiovascular Surgery, Institute for Clinical and Experimental Medicine, Prague, \\ Czech Republic, ${ }^{2}$ Center for Experimental Medicine, Institute for Clinical and Experimental \\ Medicine, Prague, Czech Republic, ${ }^{3}$ Department of Pathophysiology, Second Faculty of Medicine, \\ Charles University, Prague, Czech Republic, ${ }^{4}$ Department of Cardiology, Institute for Clinical and \\ Experimental Medicine, Prague, Czech Republic, ${ }^{5}$ Department of Renal and Body Fluid Physiology, \\ Mossakowski Medical Research Centre, Polish Academy of Sciences, Warsaw, Poland, ${ }^{6}$ ELLA-CS, \\ Ltd., Hradec Králové, Czech Republic
}

Received April 30, 2018

Accepted February 20, 2019

Epub Ahead of Print June 6, 2019

\begin{abstract}
Summary
An important complication of the prolonged left ventricle assist device support in patients with heart failure is unloading-induced cardiac atrophy which proved resistant to various treatments. Heterotopic heart transplantation $\left(\mathrm{HT}_{\mathrm{x}}\right)$ is the usual experimental model to study this process. We showed previously that implantation of the newly designed intraventricular spring expander can attenuate the atrophy when examined after $\mathrm{HT}_{\mathrm{x}}$ in the failing heart (derived from animals with established heart failure). The present study aimed to examine if enhanced isovolumic loading achieved by implantation of the expander would attenuate cardiac post- $\mathrm{HT}_{\mathrm{x}}$ atrophy also in the healthy heart. Cardiac atrophy was assessed as the ratio of the transplanted-to-native heart weight $(\mathrm{HW})$ and its degree was determined on days $7,14,21$ and 28 after $\mathrm{HT}_{\mathrm{x}}$. The transplantation resulted in $32 \pm 3,46 \pm 2,48 \pm 3$ and $46 \pm 3 \% \mathrm{HW}$ loss when measured at the four time points; implantation of the expander had no significant effect on these decreases. We conclude that enhanced isovolumic loading achieved by intraventricular implantation of the expander does not attenuate the development of cardiac atrophy after $\mathrm{HT}_{\mathrm{x}}$ in the healthy heart. This indicates that such an approach does not represent a useful therapeutic measure to attenuate the development of unloading-induced cardiac atrophy.
\end{abstract}

\section{Key words}

Cardiac atrophy • Heterotopic heart transplantation • Mechanical heart unloading $\bullet$ Spring expander

\section{Corresponding author}

L. Červenka, Center for Experimental Medicine, Institute for Clinical and Experimental Medicine, 1958/9 Vídeňská, CZ-140 00 Prague 4, Czech Republic. E-mail: luce@medicon.cz

\section{Introduction}

Heart transplantation $\left(\mathrm{HT}_{\mathrm{x}}\right)$ is in practice the only treatment approach that substantially improves survival rate in patients with end-stage heart failure (HF) (Braunwald 2015, Kassi et al. 2018, Moayedi and Ross 2017). However, application of $\mathrm{HT}_{\mathrm{x}}$ in this patient group is limited due to the scarcity of donor supply. Therefore implantation of the left ventricle assist device (LVAD) has emerged as an alternative treatment approach and is increasingly used (Drakos and Mehra 2016, Kassi et al. 2018). Application of LVAD results in unloading of the left ventricle (LV) and was reported to reverse the pathological cellular, structural and functional changes in the myocardium of patients with HF ("remodeling 
process") and therefore described as "reverse remodeling" (Birks 2013, Chaggar et al. 2016, Ibrahim et al. 2015). It has been proposed that the improvement of cardiac function after LVAD-induced mechanical unloading could eventually lead to a successful weaning from LVAD support (Birks 2013, Chaggar et al. 2016, Ibrahim et al. 2015). Unfortunately, even though the biological signs of reverse remodeling are present in the majority of patients after LVAD implantation, a clinical recovery of myocardial function that would allow termination of LVAD support was observed in 4-8\% only (Drakos and Mehra 2016, Chaggar et al. 2016, Kassi et al. 2018). The reason(s) for the discrepancy between biological and functional outcome of LVAD treatment have not been elucidated. It is notable that prolonged use of LVAD has also some detrimental effects: the unloading results in significant cardiac atrophy which is now considered the main counterindication to the successful weaning from LVAD support (Benke et al. 2017, Birks 2013, Fu et al. 2016, Heckle et al. 2016, Pokorný et al. 2014).

Many attempts have been made to minimize the said detrimental effect of long-term LVAD use, however, the therapeutic effects were not satisfactory, which underscores the need for further search for new treatment approaches (Benke et al. 2017, Fu et al. 2016, Geen et al. 1994, Heckle et al. 2016, Navarathnarajah et al. 2014, Pokorný et al. 2014, Pokorný et al. 2018a). We reported recently that implantation of the stainless steel spring expander into the LV (it provides sufficient isovolumic loading without impairing LV ejection function) attenuated the process of unloading-induced cardiac atrophy after heterotopic $\mathrm{HT}_{\mathrm{x}}$ onto the abdominal aorta of an isogenic rat recipient (a recognized model to study effects of mechanical heart unloading). This improvement was observed in the failing heart i.e. the one derived from animals with established advanced HF (Pokorný et al. $2018 b$ ). Moreover, we have also found that the natural course of unloading-induced cardiac atrophy is different in the healthy and failing hearts (Pokorný et al. 2018a). On the whole, the basic question is whether an enhancement of isovolumic loading can be used as a general therapeutic approach to prevent or at least attenuate the development of unloading-induced cardiac atrophy. All the aspects considered, we decided to examine if also in the healthy heart, isovolumic loading achieved by implantation of the spring expander into LV would attenuate the process of unloading-induced cardiac atrophy after heterotopic $\mathrm{HT}_{\mathrm{x}}$.
Our previous study employing implantation of the spring expander into the LV had a major limitation because it was not assessed if the long-term implantation of the expander does not impair cardiac function and structure of the LV in the heart after heterotopic $\mathrm{HT}_{\mathrm{x}}$ (Pokorný et al. 2018b). Therefore, we performed an additional comprehensive series of experiments in animals after heterotopic $\mathrm{HT}_{\mathrm{x}}$ with and without implantation of the spring expander into the LV, to evaluate the cardiac structure and function by echocardiography.

\section{Methods}

\section{Ethical approval, animals, heart transplantation (HTx)}

The studies were performed in accordance with the guidelines and practices established by the Animal Care and Use Committee of the Institute for Clinical and Experimental Medicine, Prague. The present study used adult male Lewis rats (an inbred strain in which no need for post-transplantation immunosuppression is required) at the initial age of 10-11 weeks and body weight 290-320 g. The rats were purchased from Charles River Laboratories (Velaz, Prague, Czech Republic). The heterotopic $\mathrm{HT}_{\mathrm{x}}$, originally described by Ono and Lindsey (Ono and Lindsey 1969) and employed by many groups including ours, was used as the model to mimic the consequences of mechanical heart unloading (Benke et al. 2017, Brinks et al. 2014, Fu et al. 2016, Geen et al. 1994, Klein et al. 1991, Kolář et al. 1996, Navarathnarajah et al. 2014, Pokorný et al. 2014, Pokorný et al. 2018a, Pokorný et al. 2018b).

\section{Experimental design}

Series 1: Effects of enhanced isovolumic loading induced by implantation of the spring expander into the LV on the cardiac atrophy after heterotopic HTx in healthy hearts

$\mathrm{HT}_{\mathrm{x}}$ of healthy heart was performed and, in appropriate groups, implantation into the left ventricle of the stainless steel three-branch expander (briefly: "expander") was performed through LV apex incision. For healthy hearts the expanders with branch length of $6 \mathrm{~mm}$ were used (Fig. 1). The same types of expanders were used in our recent study with failing hearts, except that the branch was now shortened from 9 to $6 \mathrm{~mm}$, based on the assessment of the LV dimensions in healthy animals. The characteristics of the stainless wire were identical as employed in our previous study: $0.17 \mathrm{~mm}$ in diameter, 316 LVM, Fort Wayne Metal was used. Its 


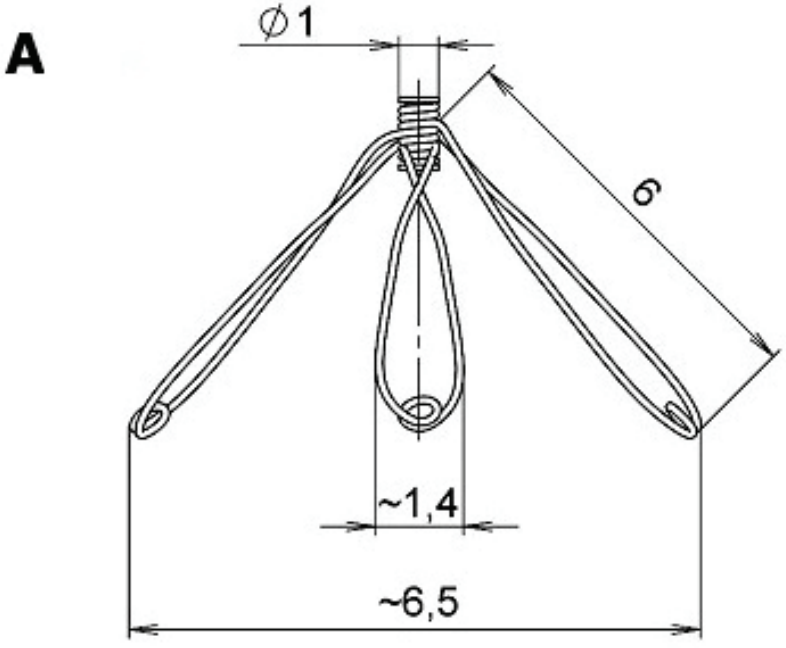

B

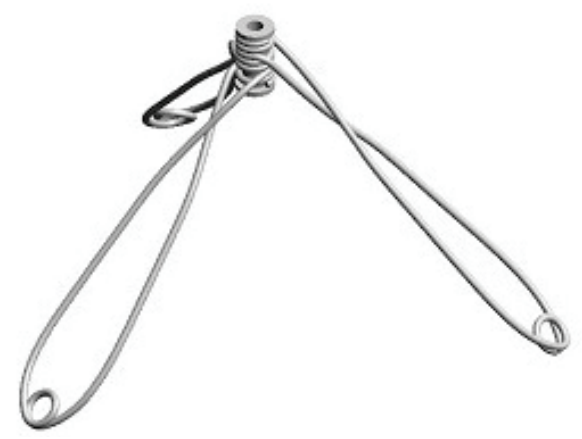

Fig. 1. Diagramatic presentation of the spring expander with branch lengths of $6 \mathrm{~mm}(A)$ and the general view of the device (B).

A

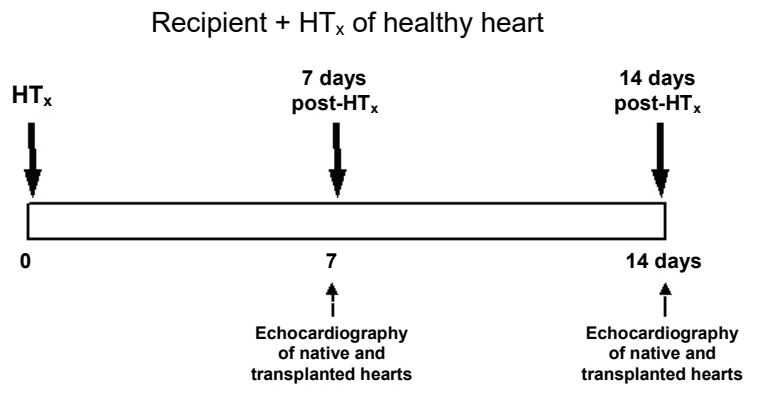

B

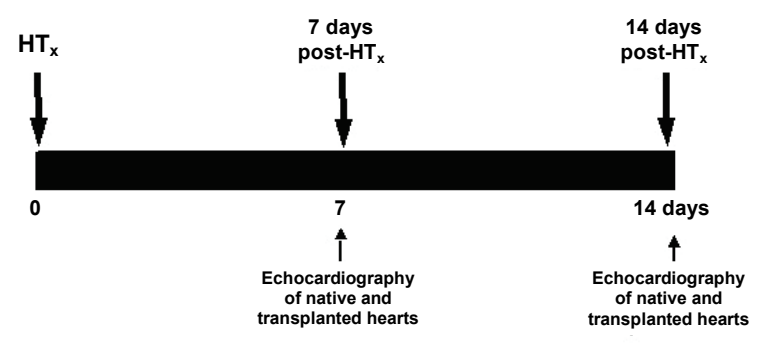

Fig. 2. An outline of the set of experimental groups for series 1 : healthy animals after heterotopic heart transplantation $\left(H T_{x}\right)$ either without (A) or with (B) implantation of the expander. chemical composition was as follows (\%): carbon 0.023 , manganese 1.84 , silicon 0.37 , phosphorus 0.014 , sulphur 0.001, chromium 17.57, nickel 14.68, molybdenum 2.79, copper 0.03 , nitrogen 0.03 and iron to balance of $100 \%$. Elastic and mechanical properties of spring expanders were measured on the miniaturized compression device and the stress-strain relationship was analyzed as described by Lossef et al. (1994).

The degree of cardiac atrophy was evaluated as the weight of total heart and, separately, of its individual structural components [i.e. $\mathrm{LV}+$ septum and right ventricle (RV)]. The degree of cardiac atrophy was expressed as percent decreases in the whole heart weight, and LV and RV weights of the hearts after the $\mathrm{HT}_{\mathrm{x}}$. This approach was chosen in order to maintain the same mode of presentation as in our recent study which explored the effects of implantation of the expander on the course of unloading-induced cardiac atrophy in failing hearts (Pokorný et al. 2018b). Unfortunately, for evaluation of the degree of cardiac atrophy we could not use HW of the donor's heart before and after $\mathrm{HT}_{\mathrm{x}}$. This was so because with the classical heterotopic $\mathrm{HT}_{\mathrm{x}}$ the donor's heart is immediately placed in cold cardioplegia solution, which precludes precise determination of heart weight. The following experimental groups were examined $(n=11$ in each group):

1. Lewis rats (recipient) $+\mathrm{HT}_{\mathrm{x}}$ of healthy donor's heart (7 days),

2. Recipient $+\mathrm{HT}_{\mathrm{x}}$ of healthy heart (14 days),

3. Recipient $+\mathrm{HT}_{\mathrm{x}}$ of healthy heart (21 days),

4. Recipient $+\mathrm{HT}_{\mathrm{x}}$ of healthy heart (28 days),

5. Recipient $+\mathrm{HT}_{\mathrm{x}}$ of healthy heart + implantation of expander ( 7 days),

6. Recipient $+\mathrm{HT}_{\mathrm{x}}$ of healthy heart + implantation of expander (14 days),

7. Recipient $+\mathrm{HT}_{\mathrm{x}}$ of healthy heart + implantation of expander (21 days),

8. Recipient $+\mathrm{HT}_{\mathrm{x}}$ of healthy heart + implantation of expander (28 days).

The experimental design used in this series is outlined in Figure 2. At the end of experiments, the hearts were excised, blood was removed from the chambers by gentle compression, and the hearts' wet weight was determined. In separate appropriately matched experimental groups ( $\mathrm{n}=9$ in each) the hearts were harvested for histological examination of the myocardium as described previously (Kolář et al. 1996, Pokorný et al. 2018a). Analysis of LV and RV fibrosis was performed in 
sections stained with Picrosirius red (Direct Red 80, Sigma Aldrich, MO, USA) as described in detail previously (Hampl et al. 2015, Kolář et al. 1996, Pokorný et al. 2018a). Briefly, the interstitial collagen was analyzed in polarized light using 10 images of the LV and 5 images of a RV scanned from a midmyocardium, without perivascular areas (magnification 200x, microscope Nikon eclipse Ni-E, camera Nikon DS-L3, Tokyo, Japan). The per cent area of myocardial fibrosis was calculated semiquantitatively, using the imaging software NIS-Elements Ar (LIM, Prague, Czech Republic).

Series 2: Echocardiographic assessment of the effects of enhanced isovolumic loading induced by implantation of the spring expander into the LV on the basal cardiac function parameters after heterotopic HTx (native and transplanted hearts)

Animals were prepared as described in series 1 and the primary aim of this series was to evaluate the cardiac function and structure of the native and transplanted hearts and effects of expander implantation on these cardiac parameters. Echocardiographic examination was performed 7 and 14 days after $\mathrm{HT}_{\mathrm{x}}$, by methods described previously and also employed by our group (xxx). Briefly, the animals were anaesthetized with $4 \%$ isofluran combined with $3 \mathrm{l} / \mathrm{min}$ oxygen; the ventral thorax and abdomen area was shaved. During the image acquisition, the rats were maintained under isoflurane anesthesia (2-2.3\%, at oxygen flow of $11 / \mathrm{min}$; if necessary, the dosage was slightly altered, depending on the animal's weight, its reaction and breathing). and fixed in the supine position. Before acquisition of standardized B-Mode and M-Mode images, the implanted hearts were screened for the presence of thrombi (defined as hyperechogenic structures inside heart cavities), for aortic insufficiency (defined as any regurgitation detected below aortic wave by color Doppler), and for any other major abnormalities. For standard measurements of cardiac parameters, B-Mode and M-Mode images were recorded in parasternal long axis view (PSLAX) and parasternal short axis view (PSAX) at the papillary muscle level. Morphological parameters of the LV, including dimensions of LV inner diameter; anterior and posterior walls at systole and diastole were measured in M-mode from long and short axis sections as previously described (Hanton et al. 2008) and employed in our laboratory (Beneš et al. 2011, Červenka et al. 2015a, Červenka et al. 2015b) The function of the LV was assessed in the native and transplanted hearts. For each parameter the mean of 3 optimally obtained measurements was used. All ultrasound studies were done by Vevo ${ }^{\circledR} 2100$ Imaging System with the MS250S transducer (13-24 MHz), (FUJIFILM VisualSonics, Inc., Toronto, Ontario, Canada). Immediately after echocardiography the animals were sacrificed by intraperitoneal injection of thiopenthal in the lethal dose, and LV weights (LV + septum weights) were assessed in the native and transplanted hearts. The following experimental groups were examined ( $\mathrm{n}=7$ in each group):

1. Recipient $+\mathrm{HT}_{\mathrm{x}}$ of healthy heart (7 days),

2. Recipient $+\mathrm{HT}_{\mathrm{x}}$ of healthy heart (14 days),

3. Recipient $+\mathrm{HT}_{\mathrm{x}}$ of healthy heart + implantation of expander (7 days),

4. Recipient $+\mathrm{HT}_{\mathrm{x}}$ of healthy heart + implantation of expander (14 days),

The experimental design used in this series is outlined in Figure 3.

\section{A Recipient $+\mathrm{HT}_{\mathrm{x}}$ of healthy heart}

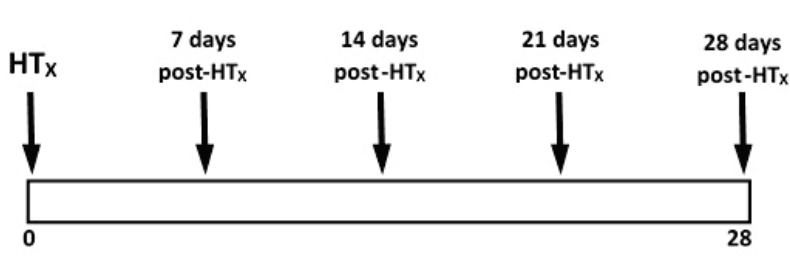

B Recipient $+\mathrm{HT}_{\mathrm{x}}$ of healthy heart + expander

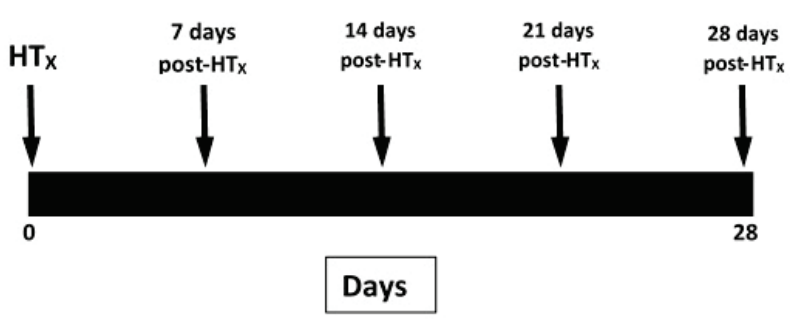

Fig. 3. An outline of the set of experimental groups for series 2: healthy animals after heterotopic heart transplantation $\left(\mathrm{HT}_{\mathrm{x}}\right)$ either without (A) or with (B) implantation of the expander.

\section{Statistical Analyses}

All values are expressed as mean \pm SEM. Using the Graph-Pad Prism software (Graph Pad Software, San Diego, CA, USA), statistical analysis was done by Student's t-test, Wilcoxon's signed-rank test for unpaired data, or one-way analysis of variance (ANOVA) when appropriate. Values exceeding $95 \%$ probability limits $(p<0.05)$ were considered statistically significant. 
Table 1. The weights of the native heart (i.e. recipient heart) and the transplanted heart (i.e. donor's heart) and of the individual structural components after heterotopic heart transplantation (HTX). Native heart values served as basal values (100 \%) for evaluation of the process of cardiac atrophy in animals after HTX.

\begin{tabular}{|c|c|c|c|c|c|c|}
\hline \multirow[b]{2}{*}{ Group } & \multicolumn{6}{|c|}{ Parameter } \\
\hline & $\begin{array}{c}\text { HW (mg) } \\
\text { (native) }\end{array}$ & $\begin{array}{c}\text { HW (mg) } \\
\left(\mathrm{HT}_{\mathrm{X}}\right)\end{array}$ & $\begin{array}{c}\text { LVW (mg) } \\
\text { (native) }\end{array}$ & $\begin{array}{c}\text { LVW (mg) } \\
\left(\mathrm{HT}_{\mathrm{x}}\right)\end{array}$ & $\begin{array}{c}\text { RVW (mg) } \\
\text { (native) }\end{array}$ & $\begin{array}{c}\mathrm{RVW}(\mathrm{mg}) \\
\left(\mathrm{HT}_{\mathrm{X}}\right)\end{array}$ \\
\hline $\begin{array}{l}\text { Recipient }+H T_{X} \text { of healthy } \\
\text { donor's heart without expander } \\
\left(7 \text { days after } H T_{X}\right)\end{array}$ & $1055 \pm 37$ & $717 \pm 21^{*}$ & $673 \pm 21$ & $478 \pm 17^{*}$ & $219 \pm 9$ & $114 \pm 6^{*}$ \\
\hline $\begin{array}{l}\text { Recipient }+H T_{X} \text { of healthy } \\
\text { donor's heart without expander } \\
\left(14 \text { days after } H T_{X}\right)\end{array}$ & $1014 \pm 31$ & $548 \pm 19^{* \#}$ & $677 \pm 19$ & $359 \pm 17^{\text {*\# }}$ & $204 \pm 11$ & $88 \pm 7^{* \# \#}$ \\
\hline $\begin{array}{l}\text { Recipient }+H T_{X} \text { of healthy } \\
\text { donor's heart without expander } \\
\left(21 \text { days after } H T_{X}\right)\end{array}$ & $1126 \pm 34$ & $586 \pm 22^{* \#}$ & $695 \pm 22$ & $375 \pm 18^{* \#}$ & $214 \pm 9$ & $96 \pm 8^{* \#}$ \\
\hline $\begin{array}{l}\text { Recipient }+H T_{X} \text { of healthy } \\
\text { donor's heart without expander } \\
\left(28 \text { days after } H T_{X}\right)\end{array}$ & $1090 \pm 29$ & $589 \pm 21^{* \#}$ & $701 \pm 22$ & $323 \pm 24^{\text {*\# }}$ & $223 \pm 11$ & $100 \pm 11^{\text {*\# }}$ \\
\hline $\begin{array}{l}\text { Recipient }+H T_{X} \text { of healthy } \\
\text { donor's heart }+ \text { implantation of } \\
\text { expander } \\
\left(7 \text { days after } H T_{X}\right)\end{array}$ & $1056 \pm 39$ & $771 \pm 29^{*}$ & $674 \pm 26$ & $498 \pm 28^{*}$ & $212 \pm 15$ & $115 \pm 9^{*}$ \\
\hline $\begin{array}{l}\text { Recipient }+H T_{X} \text { of healthy } \\
\text { donor's heart }+ \text { implantation of } \\
\text { expander } \\
\left(14 \text { days after } H T_{X}\right)\end{array}$ & $1045 \pm 43$ & $606 \pm 19^{* \#}$ & $667 \pm 25$ & $367 \pm 18^{* \#}$ & $209 \pm 16$ & $100 \pm 7^{* \#}$ \\
\hline $\begin{array}{l}\text { Recipient }+H T_{X} \text { of healthy } \\
\text { donor's heart }+ \text { implantation of } \\
\text { expander } \\
\left(21 \text { days after } H T_{X}\right)\end{array}$ & $1161 \pm 42$ & $662 \pm 29^{* \#}$ & $719 \pm 33$ & $395 \pm 21^{\text {*\# }}$ & $218 \pm 18$ & $109 \pm 11^{\text {*\# }}$ \\
\hline $\begin{array}{l}\text { Recipient }+H T_{X} \text { of healthy } \\
\text { donor's heart }+ \text { implantation of } \\
\text { expander } \\
\left(28 \text { days after } H T_{X}\right)\end{array}$ & $1117 \pm 41$ & $670 \pm 34^{* \#}$ & $724 \pm 35$ & $369 \pm 27^{* \#}$ & $218 \pm 20$ & $111 \pm 12^{\text {*\# }}$ \\
\hline
\end{tabular}

Values are means $\pm \mathrm{SEM}$. $\mathrm{HT}_{\mathrm{x}}$, heterotopic heart transplantation; HW, heart weight; LVW, left ventricle weight; RVW, right ventricle weight; ${ }^{*} \mathrm{P}<0.05$ vs. values from native heart at the same time point. ${ }^{\#} \mathrm{P}<0.05$ vs. values observed 7 days after $\mathrm{HT}_{\mathrm{x}}$.

\section{Results}

Series 1: Effects of enhanced isovolumic loading induced by implantation of the spring expander into the LV on the cardiac atrophy after heterotopic HTx in healthy hearts

Table 1 summarizes HW, LV weight (LVW) and RV weight (RVW) of native (used as $100 \%$ controls) and transplanted hearts, in absolute values, measured 7, 14, 21 and 28 days after $\mathrm{HT}_{\mathbf{x}}$.

As shown in Fig. 4A, 7-day unloading obtained by $\mathrm{HT}_{\mathrm{x}}$ in healthy hearts caused a significant decrease in whole HW $(-32 \pm 3 \%)$, which became more pronounced by day $14(-46 \pm 2 \%)$; thereafter no further progress was seen on days 21 and 28 after $\mathrm{HT}_{\mathrm{x}}$.

As shown in Fig. 4B, the dynamics of $\mathrm{LV}$ atrophy displayed an almost identical pattern as that of the whole heart.

As shown in Fig. $4 \mathrm{C}, \mathrm{RV}$ atrophy after $\mathrm{HT}_{\mathrm{x}}$ exhibited a pattern similar as observed in the whole heart; surprisingly, the change was more pronounced already on 
day 7 after $\mathrm{HT}_{\mathrm{x}}$.

The data of Fig. 4 shows that in healthy animals, implantation of the expander did not have any significant effect (at all-time points) on the decreases in whole HW, LVW and RVW.

Figure 5 summarizes the data on the index of myocardial fibrosis (\%) in the LV (Fig. 5A) and RV (Fig. 5B). It is seen that the degree of fibrosis was significantly lower in the LV as compared with the RV. The degree of myocardial fibrosis in the LV of the healthy native hearts (i.e. the native hearts of the recipient) was significantly lower than in the RV throughout the 28-day observation period and was not altered after $\mathrm{HT}_{\mathrm{x}}$, nor did implantation of the expander after $\mathrm{HT}_{\mathrm{x}}$ alter it.

Figure 6 shows representative images of myocardial fibrosis in the LV and the RV of the healthy native heart.

Series 2: Echocardiographic assessment of the effects of enhanced isovolumic loading induced by implantation of the spring expander into the $L V$ on the basal cardiac function parameters after heterotopic HTx

Table 2 summarizes the evaluation of cardiac function by echocardiography. These data show that throughout the experimental period the native hearts exhibited normal parameters characteristic for healthy rats, as repeatedly shown in our previous studies (Beneš et al. 2011, Červenka et al. 2015a, Červenka et al. 2015b). Neither $\mathrm{HT}_{\mathrm{x}}$, nor $\mathrm{HT}_{\mathrm{x}}$ with implantation of the expander changed the cardiac function parameters of the native hearts. The function of the post- $\mathrm{HT}_{\mathrm{x}}$ heart exhibited all the characteristics that were already reported for the volume-unloaded heterotopic heart transplants (Didié et al. 2013). Specifically, there was a decrease in LV diameter in diastole, in the stroke volume, cardiac output, LV anterior and LV posterior wall thickness in systole, LV fractional shortening and LV ejection fraction. In addition, implantation of the expander resulted in a significant increase in LV diameter in systole as compared with values obtained in heterotopic heart transplants without the expander. In addition, in each of the experimental group, there was one animal which showed moderate (hemodynamically unimportant) aortal insufficiency in the heterotopic heart transplant. Moreover, in each experimental group, two animals showed thrombi either in the LV or RV (in one case in both) in heterotopic heart transplant, irrespective of the expander implantation.
A

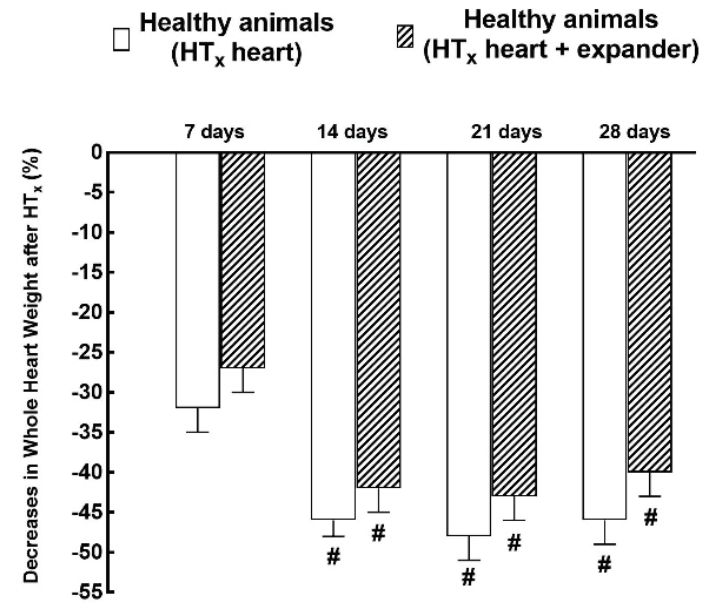

B

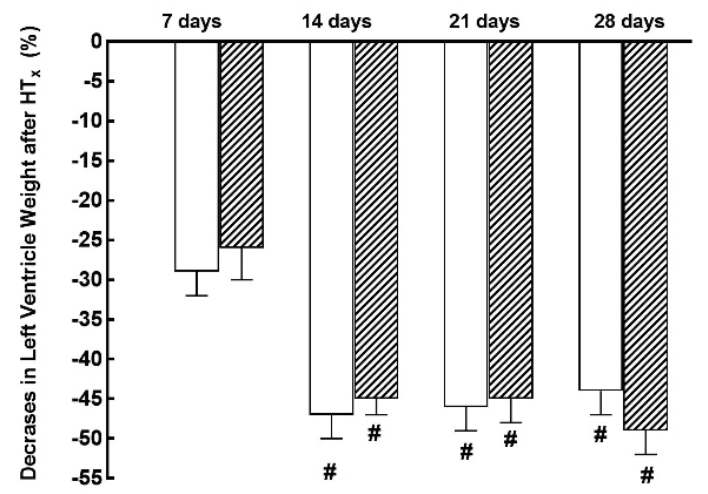

C

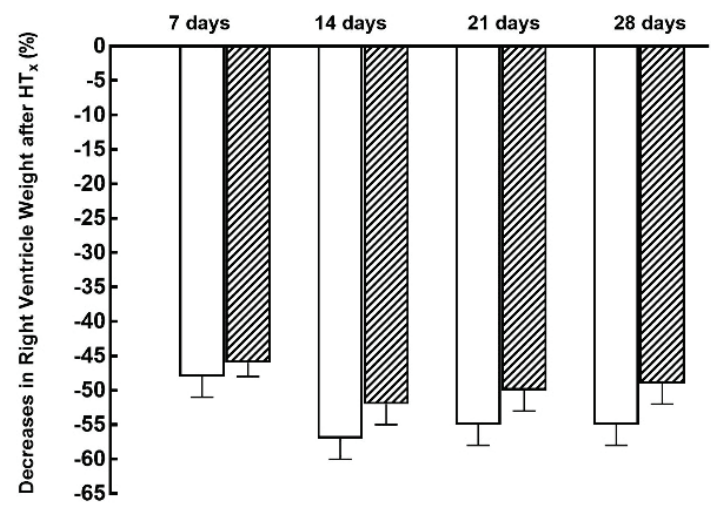

Fig. 4. Effect implantation of the spring expander on the course of cardiac atrophy in response to mechanical heart unloading induced by heterotopic heart transplantation $\left(\mathrm{HT}_{\mathrm{x}}\right)$ in healthy animals. Data are expressed as percent decreases from the values for the native healthy heart (100\%): (A) changes in whole heart weight, (B) changes in left ventricle weight, (C) changes in right ventricle weight. ${ }^{\#} \mathrm{P}<0.05$ versus the values for the animals studied 7 days after $\mathrm{HT}_{\mathrm{x}}$.

As shown in Fig. 7A, assessment of the LV weight by echocardiography revealed excellent correlation with values obtained by direct weighing of the native hearts. In the heterotopic heart transplant the correlation between values obtained by direct weighing and by echocardiography was good, however, the scatter 
A
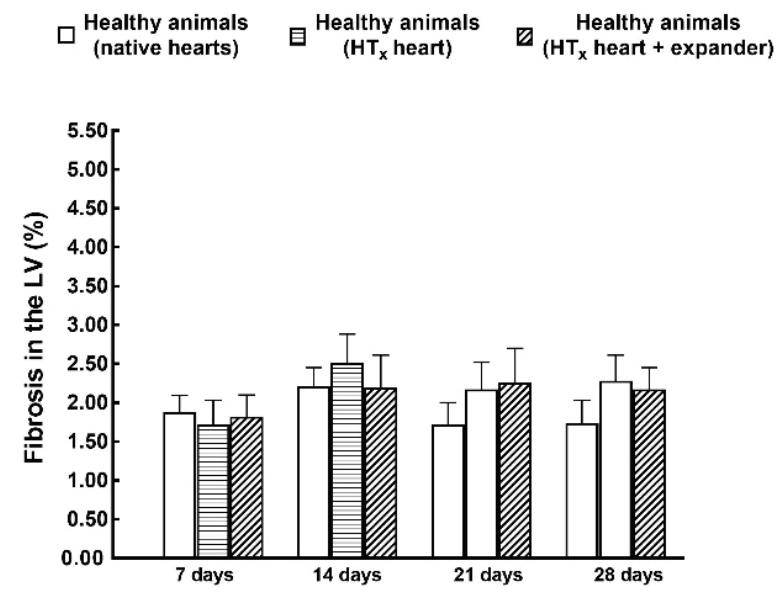

B

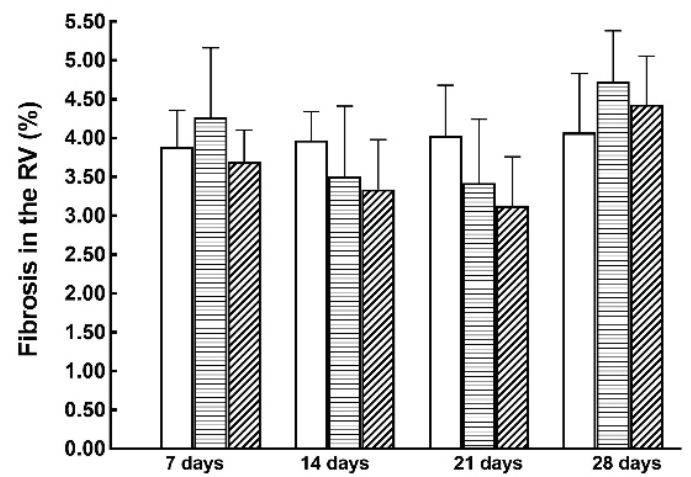

Fig. 5. The index of myocardial fibrosis for the left ventricle (LV) (A) and the right ventricle (RV) (B) in the native hearts, and effects of heterotopic heart transplantation $\left(\mathrm{HT}_{\mathrm{x}}\right)$ without and with spring expander implantation.

of values obtained by echocardiography was more pronounced; nevertheless, the values were not altered by implantation of the expander.

As shown in Fig. 7B, when estimated on day 7, the extent of LV atrophy was overestimated by echocardiography as compared with direct weighing, however, on day 14 almost identical respective values were obtained.

Figures 8 and 9 show representative images of echocardiographic assessment of the hearts after HTx, including those in some pathological conditions, e.g. aortic regurgitation and the thrombi in the LV or RV of the transplanted hearts.

\section{Discussion}

The first critically important finding of the present study is that enhancement of isovolumic loading induced by implantation of the spring expander into the LV of the healthy heart did not attenuate the development post- $\mathrm{HT}_{\mathrm{x}}$ cardiac atrophy. This was documented by determination of decreases in whole $\mathrm{HW}, \mathrm{LV}$ and RV
A

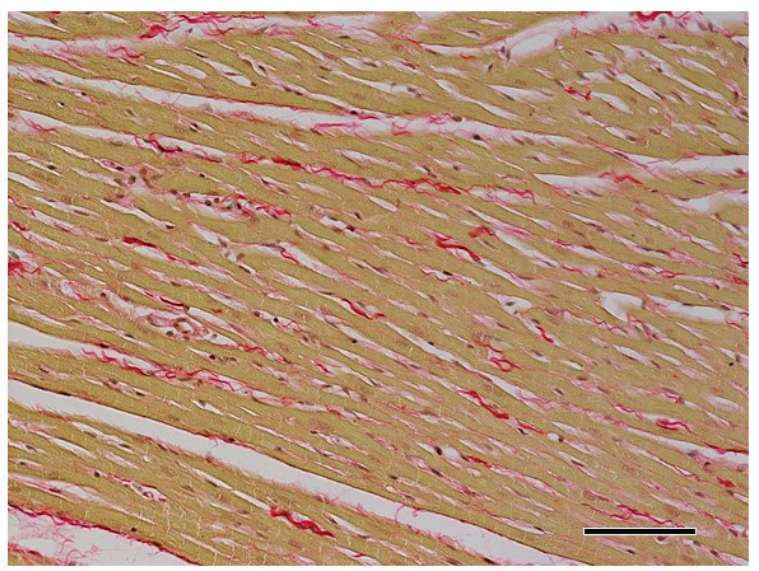

B

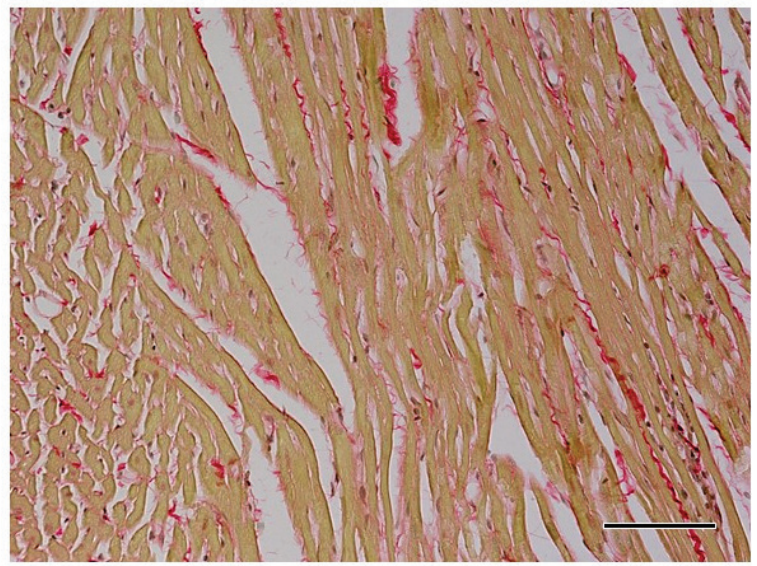

Fig. 6. Representative images of the left (A) and right (B) ventricle of the native heart of the healthy animals. Sections are stained with Picrosirius red (magnification 200x); in these brightfield microscopy images the collagen is red against a pale yellow background. The fibrosis in the left ventricle of this particular healthy animal was estimated at $1.93 \%$. The fibrosis in the right ventricle of this particular healthy animal was estimated at $3.74 \%$. Scale bar in the figure is $100 \mu \mathrm{m}$.

weights of the transplanted heart when compared with weights of the native heart. This finding is surprising and in striking contrast to our recent discovery that application of the expander markedly attenuated the development of post- $\mathrm{HT}_{\mathrm{x}}$ cardiac atrophy in the failing heart (Pokorný et al. 2018b). We cannot provide any clear explanation for such discrepant effects of the implantation on the course of unloading-induced cardiac atrophy in healthy and failing hearts.

In this context, it is important to acknowledge that the idea to increase isovolumic loading by implantation of the expander into the $\mathrm{LV}$, as employed in our present and previous study (Pokorný et al. 2018b), was inspired by a pioneering study by Klein and co-workers (Klein et al. 1991) who found that inflation of a latex balloon in the LV provided an isovolumic load which prevented the development of cardiac atrophy after 
A

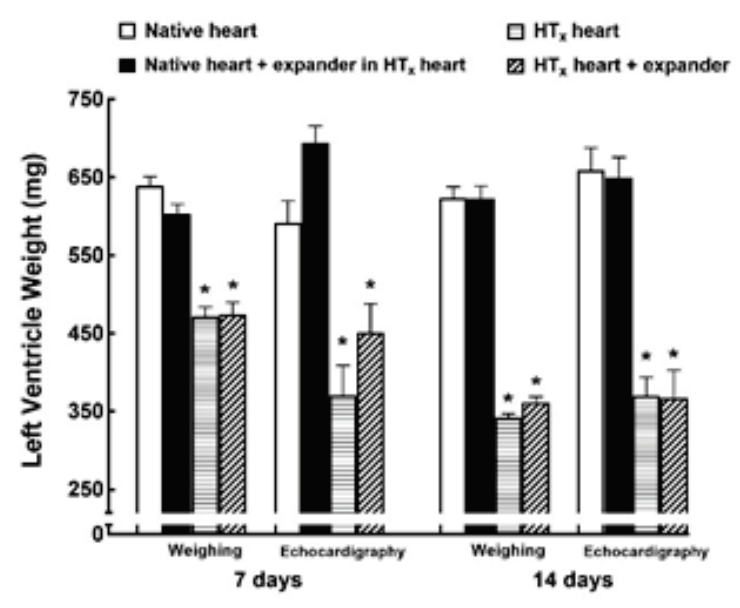

B

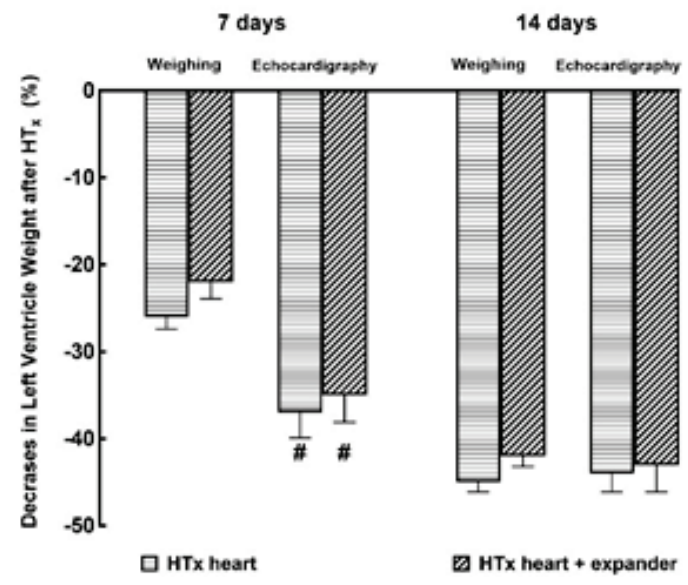

Fig. 7. (A) The left ventricle weight evaluated by direct weighing and indirectly by echocardiography: effect implantation of the spring expander on the course of weight change in native hearts and in unloaded hearts after heterotopic heart transplantation $\left(H T_{x}\right)$ in healthy animals. (B) Effect implantation of the spring expander on the course of left ventricle atrophy in response to mechanical unloading (after $\mathrm{HT}_{\mathrm{x}}$ ) in healthy animals: data are expressed as percent decreases from the values for the native left ventricle weight $(100 \%) . * P<0.05$ versus native hearts at the same time point. ${ }^{\#} \mathrm{P}<0.05$ versus values obtained by direct weighing at the same time point.

$\mathrm{HT}_{\mathrm{x}}$ in healthy heart. Unfortunately, this approach is not applicable in the clinic: in patients with LVAD this procedure would cause obstruction of the LV and failure of LVAD function.

It is admitted that the lack of "anti-atrophic" actions of the expander as observed here is extremely surprising, considering the sound knowledge that the cardiac work is the major determinant of the heart mass (Korecký and Masika 1991, Lee et al. 2016). It would be expected that enhancing this work by isovolumic loading (induced by implantation of the expander, a procedure that does not impair LV function) should attenuate the development of unloading-induced cardiac atrophy in the healthy just as it did in the failing heart (Pokorný et al. 2018b). Regardless of the exact explanation, the present findings indicate that evaluation of the effectiveness of pharmacological and/or non-pharmacological measures aimed at attenuation of unloading-induced atrophy should be based on studies of the healthy as well as failing hearts. Evidently, our present and previous results show that cardiac atrophy after $\mathrm{HT}_{\mathrm{x}}$ is more prominent in the failing heart (Pokorný et al. 2018a, Pokorný et al. 2018b). Similarly, the responses to attempts to prevent or attenuate this process might differ. This view has now found growing recognition among investigators interested in various aspects of the process of unloading-induced myocardial remodeling after $\mathrm{HT}_{\mathrm{x}}$ (Benke et al. 2017, Brinks et al. 2014, Fu et al. 2016).

Of special interest is our observation that the decreases in RV weights of the transplanted heart reached the maximum on day 7 after $\mathrm{HT}_{\mathrm{x}}$ whereas those of the $\mathrm{LV}$ were delayed and did not reach the maximum value until the day 14 , We cannot provide any satisfactory explanation for this difference. In our recent study, a similar one but performed with the failing hearts, the course of unloading-induced cardiac atrophy was identical in the RV and LV (Pokorný et al. 2018a, Pokorný et al. 2018b). Evidently, the course of unloading-induced cardiac atrophy might significantly differ, depending on the condition of the heart (healthy or failing), and may also show differences between individual heart structural compartments; such possible differentiation should be considered in designing future studies.

The second important set of findings relates to results of studies evaluating the effect of long-term implantation of the expander on the cardiac function and structure of the native and, in particular, transplanted hearts. Notably, earlier studies revealed that permanent placement of an inflated balloon in the LV not only caused obstruction of the LV, but also elicited major structural changes of the transplanted heart (Galiňanes et al. 1991, Klein et al. 1991). Therefore, our present findings are critically important for several reasons.

First, we found that the function of the native hearts of the recipient was within physiological range for healthy animals (Beneš et al. 2011, Červenka et al. 2015a, Červenka et al. 2015b). Thence forward, the $\mathrm{HT}_{\mathrm{x}}$ with implantation of the expander did not alter cardiac function of the orthotopic native hearts as compared with animals that underwent only $\mathrm{HT}_{\mathrm{x}}$; this excludes any possible indirect effects (e.g. due to secondary changes in hormonal environment) on the course of cardiac atrophy after $\mathrm{HT}_{\mathrm{x}}$. 
Table 2. Echocardiography analyses of left ventricle function and morphology in native heart (i.e. recipient heart) and transplanted heart (i.e. donor's heart) after heterotopic heart transplantation (HTx).

\begin{tabular}{|c|c|c|c|c|c|c|c|c|}
\hline \multirow[b]{2}{*}{ Parameter } & \multicolumn{2}{|c|}{ Group 1} & \multicolumn{2}{|c|}{ Group 2} & \multicolumn{2}{|c|}{ Group 3} & \multicolumn{2}{|c|}{ Group 4} \\
\hline & native & $\mathbf{H T}_{\mathbf{x}}$ & native & $\mathbf{H T}_{\mathbf{x}}$ & native & $\mathbf{H T}_{\mathbf{x}}$ & native & $\mathbf{H T}_{\mathbf{x}}$ \\
\hline$L V D D(\mathrm{~mm})$ & $6.49 \pm 0.14$ & $5.09 \pm 0.14^{*}$ & $6.61 \pm 0.11$ & $5.14 \pm 0.09^{*}$ & $6.72 \pm 0.09$ & $5.11 \pm 0.11^{*}$ & $6.71 \pm 0.14$ & $5.15 \pm 0.10^{*}$ \\
\hline $\operatorname{LVSD}(\mathrm{mm})$ & $3.49 \pm 0.12$ & $4.19 \pm 0.11$ & $3.52 \pm 0.12$ & $4.46 \pm 0.08^{*}$ & $3.57 \pm 0.18$ & $4.19 \pm 0.12$ & $3.49 \pm 0.15$ & $4.51 \pm 0.09^{*}$ \\
\hline LVFS (\%) & $45.1 \pm 1.9$ & $16.8 \pm 2.3^{*}$ & $47.9 \pm 2.1$ & $13.1 \pm 2.1^{*}$ & $48.1 \pm 2.5$ & $17.1 \pm 2.8^{*}$ & $48.8 \pm 2.2$ & $14.1 \pm 1.9^{*}$ \\
\hline $\operatorname{LVEF}(\%)$ & $75.5 \pm 1.8$ & $32.4 \pm 3.1^{*}$ & $77.5 \pm 1.4$ & $25.5 \pm 3.7^{*}$ & $75.7 \pm 2.4$ & $31.8 \pm 3.6^{*}$ & $78.5 \pm 1.6$ & $24.1 \pm 2.1^{*}$ \\
\hline$S V(\mu l)$ & $160 \pm 9.2$ & $41 \pm 6.8^{*}$ & $180 \pm 6.4$ & $31 \pm 5.1^{*}$ & $182 \pm 5.4$ & $44 \pm 8.9^{*}$ & $186 \pm 9.2$ & $35 \pm 3.1^{*}$ \\
\hline $\mathrm{CO}(\mathrm{ml} / \mathrm{min})$ & $64.9 \pm 3.4$ & $13.1 \pm 1.9^{*}$ & $67.7 \pm 2.6$ & $9.6 \pm 1.1^{*}$ & $70.6 \pm 1.6$ & $15.1 \pm 3.1^{*}$ & $71.5 \pm 3.2$ & $8.8 \pm 0.9^{*}$ \\
\hline$L W A W T d(\mathrm{~mm})$ & $1.68 \pm 0.06$ & $1.54 \pm 0.11$ & $1.79 \pm 0.04$ & $1.74 \pm 0.11$ & $1.66 \pm 0.05$ & $1.81 \pm 0.16$ & $1.70 \pm 0.05$ & $1.56 \pm 0.1$ \\
\hline$L W P W T d(\mathrm{~mm})$ & $1.76 \pm 0.10$ & $1.41 \pm 0.11$ & $1.76 \pm 0.08$ & $1.51 \pm 0.12$ & $1.81 \pm 0.06$ & $1.57 \pm 0.10$ & $1.79 \pm 0.06$ & $1.46 \pm 0.08$ \\
\hline$L W A W T S / L W A W T d$ & $1.51 \pm 0.06$ & $1.10 \pm 0.06^{*}$ & $1.60 \pm 0.07$ & $1.04 \pm 0.02^{*}$ & $1.68 \pm 0.06$ & $1.11 \pm 0.03^{*}$ & $1.72 \pm 0.05$ & $1.09 \pm 0.02^{*}$ \\
\hline$L W P W T_{S} / L W P W T d$ & $1.59 \pm 0.08$ & $1.07 \pm 0.04^{*}$ & $1.65 \pm 0.5$ & $1.07 \pm 0.03^{*}$ & $1.62 \pm 0.06$ & $1.10 \pm 0.03^{*}$ & $1.70 \pm 0.04$ & $1.05 \pm 0.02 *$ \\
\hline
\end{tabular}

Values are means $\pm \mathrm{SEM} . \mathrm{HT}_{\mathrm{x}}$, heterotopic heart transplantation. Group 1, Recipient $+\mathrm{HT}_{\mathrm{x}}$ of healthy donor's heart without expander (7 days after $\mathrm{HT}_{\mathrm{x}}$ ); Group 2, Recipient $+\mathrm{HT}_{\mathrm{x}}$ of healthy donor's heart without expander (14 days after $\mathrm{HT}_{\mathrm{x}}$ ); Group 3, Recipient $+\mathrm{HT} \mathrm{T}_{\mathrm{x}}$ of healthy donor's heart + implantation of expander (7 days after $\mathrm{HT}_{\mathrm{x}}$ ); Group 4, Recipient $+\mathrm{HT}_{\mathrm{x}}$ of healthy donor's heart + implantation of expander (14 days after $\mathrm{HT}_{\mathrm{x}}$ ). LVDD, left ventricular diastolic diameter; LVSD, left ventricular systolic diameter; LVFS, left ventricular fractional shortening; LVEF, left ventricular ejection fraction; SV, stroke volume; CO, cardiac output; LVAWTd, left ventricular anterior wall thickness in diastole; LVPWTd, left ventricular posterior wall thickness in diastole; LVAWTs, left ventricular anterior wall thickness in systole; LVPWTs, left ventricular posterior wall thickness in systole. ${ }^{*} \mathrm{P}<0.05$ vs. values from the native heart at the same time point.

A

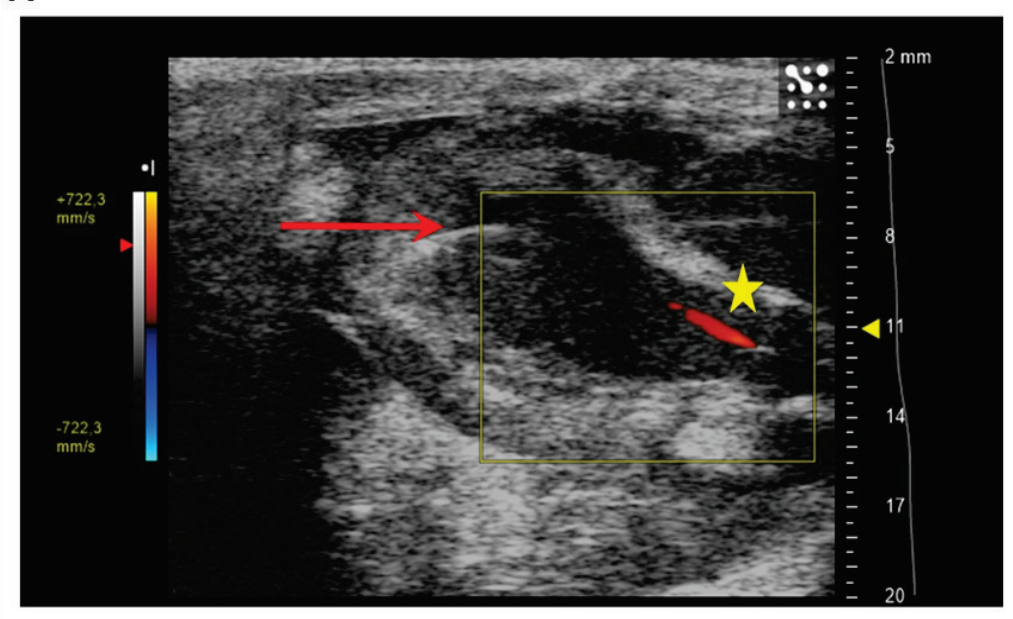

B

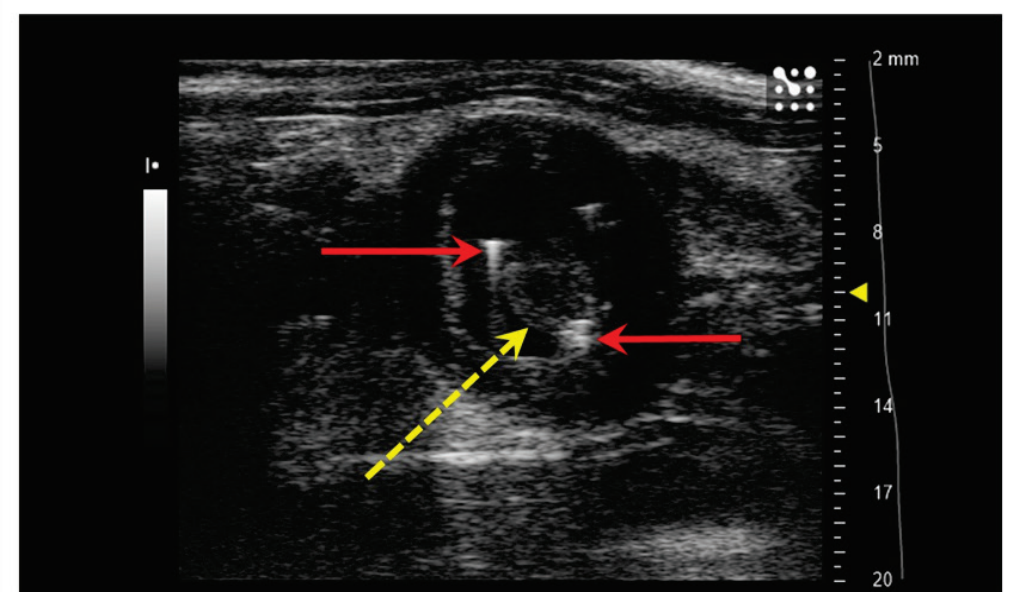

Fig. 8. Representative echocardiographic images of the heterotopic heart (A) recorded 7 days after heterotopic heart transplantation without spring expander implantation and heterotopic heart (B) recorded 7 days after heterotopic heart transplantation with spring expander implantation. Red arrows show the position of the spring expander branches in the heterotopic heart. 


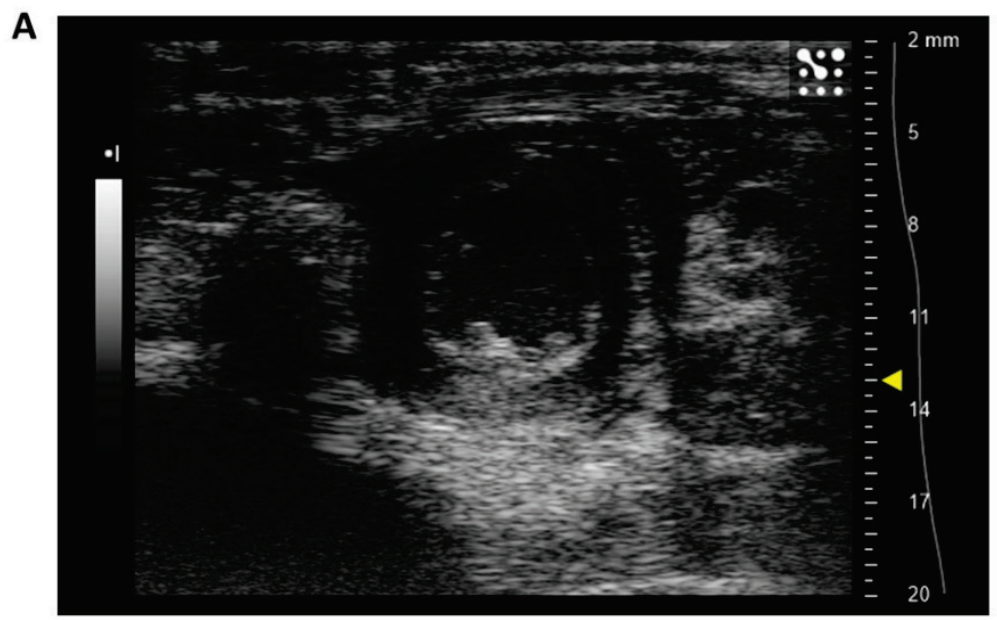

Fig. 9. Representative echocardiographic images of the heterotopic heart (A) recorded 7 days after heterotopic heart transplantation with spring expander implantation (red arrow), showing slight aortic regurgitation (yellow asterisks) and (B) the heterotopic heart recorded 7 days after heterotopic heart transplantation with spring expander implantation, showing a thrombus inside the left ventricle inner branches of the spring expander (yellow arrow)

B

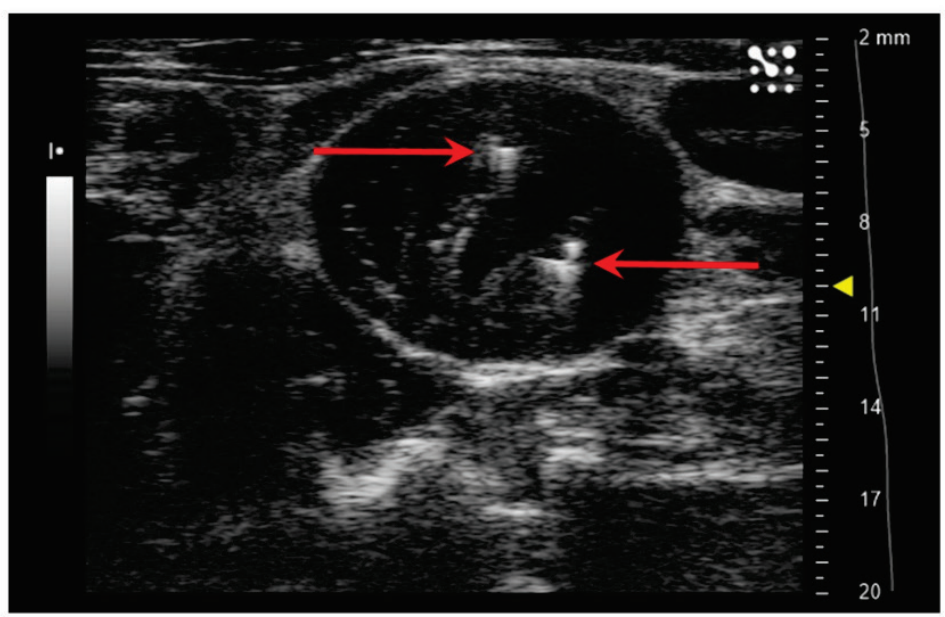

Second, the transplanted hearts studied did not reveal any important mechanical damage of the aortic valve and there were no signs of serious congestion of the $\mathrm{LV}$, similarly in $\mathrm{HT}_{\mathrm{x}}$ without or with expander implantation. The relatively high occurrence of thrombi, both in the LV or RV of the transplanted heart, was the only complication which was unrelated to expander implantation and obviously due to the absence of anticoagulation therapy in this experimental setting. In any case, the presence of thrombi did not apparently have any important influence on the course of cardiac atrophy after $\mathrm{HT}_{\mathrm{x}}$.

Third, our results show a good correlation between the assessment of the LV weight by echocardiography and by direct weighing of the transplanted heart. Admittedly, the variability of the values obtained by echocardiography was somewhat greater (irrespective of expander implantation), which further strengthens our opinion that for precise evaluation of the unloading-induced cardiac atrophy after $\mathrm{HT}_{\mathrm{x}}$, direct weighing of the heart and its individual compartments should be standard procedure.
Fourth, our echocardiographic data are typical for the volume-unloaded heart after $\mathrm{HT}_{\mathrm{x}}$, with markedly decreased stroke volume and cardiac output. (Didié et al. 2013). The slightly higher LV diameter in systole in the transplanted heart with the expander suggests that its implantation increased cardiac work in this experimental group. In addition, our data show that the LV fractional shortening and the LV anterior and posterior wall thickness in systole, the parameters of global and regional cardiac function, respectively, were reduced in the transplanted as compared with native hearts. These findings are important in that they suggest that in our experimental setting the contractile function of the LV of the chronically unloaded heart after $\mathrm{HT}_{\mathrm{x}}$ is impaired. It will be noticed that the results of earlier studies evaluating the contractile function of the heart after $\mathrm{HT}_{\mathrm{x}}$ were not consistent: some studies reported a decrease (Galiňanes et al. 1991, Galiňanes et al. 1995, Ito et al. 2003, Soppa et al. 2008) but the majority (those employing an array of imaging and functional assessment techniques) showed that despite considerable atrophy, the intrinsic contractile properties of the transplanted heart 
remained normal (Brinks et al. 2009, Didié et al. 2013, Geenen et al. 1994, Liu et al. 2015, Koláŕ et al. 1993, Kolář et al. 1995, Korecký and Rakušan 1983, Takaseya et al. 2004, Welsch et al. 2001) or even were improved as compared with the native control hearts (Ritter et al. 2000). However, it is now acknowledged that the measures of cardiac parameters have to be normalized for morphological parameters. If not, decreased contractile performance in the atrophied hearts is shown, whereas normalized parameters (in vitro evaluation of mechanical performance of the papillary muscles or in vivo pressurevolume analysis of $\mathrm{LV}$ function) suggest intact or even enhanced cardiac contractile function (Benke et al. 2017, Fu et al. 2016).

In conclusion, even with echocardiographic evaluation of the cardiac function, a limitation of our present study was that we did not perform a rigorous hemodynamic evaluation of the cardiac function by employing analyses of the LV pressure-volume relationship of the transplanted heart (Pacher et al. 2008). Only such assessment could definitely characterise the effects of expander implantation on the cardiac work and cardiac contractility of the transplanted heart. However, such evaluation would require insertion of a conductance catheter into the LV to obtain pressure-volume relationship data. While such approach is standardly employed in our laboratory in healthy rats as well as in rats with HF (Červenka et al. 2015a, Červenka et al. 2015b), we have not yet succeeded to apply it in the heart after $\mathrm{HT}_{\mathrm{x}}$ (the impediment here is the state of volumeunloading).

Another limitation of our present study is related to the model of $\mathrm{HT}_{\mathrm{x}}$. It is important to recognize that normally the transplanted heart is exposed to the same hormonal environment as the control (i.e. ortotopic native) heart: the transplanted organ is supplied by the recipient. This means that the direct or indirect effects of metabolic and hormonal factors on the course of unloading-induced cardiac atrophy after $\mathrm{HT}_{\mathrm{x}}$ can be disregarded. This is regarded a major advantage of the heterotopic $\mathrm{HT}_{\mathrm{x}}$ model (Benke et al. 2017, Fu et al. 2016, Ono and Lindsey 1969). However, in our latest study which showed that implantation of the expander attenuated cardiac atrophy in the failing heart, this heart was transplanted to a healthy recipient (Pokorný et al. 2018b). The reason was that the HF model employed was one of volume overload induced by aorto-caval fistula $(\mathrm{ACF})$; the model is well-characterized and standardly employed in our laboratory (Červenka et al. 2015a, Červenka et al. 2015b). Animals 10 weeks after ACF creation were used as heart donors, because at that time ACF animals are in the stage of advanced but still compensated HF, then they soon progress toward decompensation (Červenka et al. 2015a, Červenka et al. 2015b) and at this stage would not survive the surgical procedure of $\mathrm{HT}_{\mathrm{x}}$. Moreover, transplantation would have to be done to the site where ACF is already located. Thus, in that study the heart from the animal with advanced HF and marked activation of the circulatory hormonal systems was suddenly placed in the normal hormonal environment of a healthy animal. This situation could have some modulatory action on the course of unloadinginduced cardiac atrophy and particularly on the effect of expander implantation on this process. This line of reasoning is supported by the clinical evidence that the "reverse remodeling" and functional recovery of the LV function in patients after implantation of LVAD was significantly enhanced when intensive adjunctive pharmacological therapies aimed at normalization of the neurohormonal environment were employed (Birks et al. 2011, Catino et al. 2018). All these aspects considered, it is apparent that more studies are needed to address the above limitations and our current study provides a necessary basis for such investigations.

In conclusion, the results of the present study show that implantation of the spring expander into the LV does not attenuate the development of cardiac atrophy after $\mathrm{HT}_{\mathrm{x}}$ in the healthy heart. Considering the reservations discussed above we believe that increasing isovolumic loading using the expander may not represent a generally useful therapeutic measure to attenuate the development of unloading-induced cardiac atrophy, however, it might be of value in selected clinical conditions.

\section{Conflict of Interest}

Authors declare no conflict of interest.

\section{Acknowledgements}

This study was primarily supported by Ministry of Health of the Czech Republic grant 16-27420A awarded to Jan Pirk. 


\section{References}

BENES J, KAZDOVA L, DRAHOTA Z, HOUSTEK J, MEDRIKOVA D, KOPECKY J, KOVAROVA N, VRBACKY M, SEDMERA D, STRNAD H, KOLAR M, PETRAK J, BENADA O, SKAROUPKOVA P, CERVENKA L, MELENOVSKY V: Effects of metformin therapy on cardiac function and survival in a volume-overload model of heart failure in rats. Clin Sci 129: 29-41, 2011.

BENKE K, SAYOUR AA, MÁTYÁS C, ÁGG B, NÉMETH BT, OLÁH A, RUPPERT M, HARTYÁSZKY I, SZABLOCS Z, RADOVITS T, MERKELY B, SZABÓ G: Heterotopic abdominal rat heart transplantation as a model to investigate volume dependency of myocardial remodeling. Transplantation 101: 498-505, 2017.

BIRKS EJ: Molecular changes after left ventricular assist device support for heart failure. Circ Res 113: 777-791, 2013.

BIRKS EJ, GEORGE RS, HEDGER M, BAHRAMI T, WILTON, P, BOWLES CT, WEBB C, BOUGARD R, AMRANI M, YACOUB MH, DREYFUS G, KHAGHANI A: Reversal of severe heart failure with a continuous-flow left ventricular assist device and pharmacological therapy: a prospective study. Circulation 123: 381-390, 2011.

BRAUNWALD E: The war against heart failure. Lancet 385: 812-824, 2015.

BRINKS H, TEVAEARAI H, MUHLFELD C, BERTSHI D, GAHL B, CARREL T, GIRAURD MN: Contractile function is preserved in unloaded hearts despite atrophic remodeling. J Thorac Cardiovasc Surg 137: 742-746, 2009.

BRINKS H, GIRAUD MN, SEGISER A, FERRIÉ C, LONGNUS S, ULLRICH ND, KOCH WJ, MOST P, CARREL TP, TEVAERAI HT: Dynamic patterns of ventricular remodelling and apoptosis in hearts unloaded by heterotopic transplantation. J Heart Lung Transplant 33: 203-210, 2014.

CATINO AB, FERRIN P, WEBER-PINZON J, HORNE BD, WEBER PINZON O, KFOURY AG, MCGREATHE L, DIAKOS NA, MCKELLAR S, KOLIOPOULOU A, BONIOS MJ, AL-SARIE M, TALEB I, DRANOW E, FANG JC, DRAKOS SG: Clinical and histopathological effects of heart failure drug therapy in advanced heart failure patients on chronic mechanical circulatory support. Eur J Heart Fail 20: 164-174, 2018.

ČERVENKA L, MELENOVSKÝ V, HUSKOVÁ Z, SPORKOVÁ A, BURGELOVÁ M, ŠKAROUPKOVÁ P, HWANG SH, HAMMOCK BD, IMIG JD, SADOWSKI J: Inhibition of soluble epoxide hydrolase does not improve the course of congestive heart failure and the development of renal dysfunction in rats with volume overload induced by aorto-caval fistula. Physiol Res 64: 857-873, 2015a.

ČERVENKA L, MELENOVSKÝ V, HUSKOVÁ Z, ŠKAROUPKOVÁ P, NISHIYAMA A, SADOWSKI J: Inhibition of soluble epoxide hydrolase counteracts the development of renal dysfunction and progression of congestive heart failure in Ren-2 transgenic hypertensive rats with aorto-caval fistula. Clin Exp Pharmacol Physiol 42: 795-807, 2015b.

DIDIÉ M, BIERMANN D, BUCHERT R, HESS A, WITTKOPPER K, CHRISTALLA P, DOKER S, JEBRAN F, SCHONDUBE F, REICHENSPURNER H, EL-ARMOUCHE A, ZIMMERMANN WH: Preservation of left ventricular function and morphology in volume-loaded versus volume-unloaded heterotopic heart transplants. Am J Physiol 305: H533-H541, 2013.

DRAKOS SG, MEHRA MR: Clinical myocardial recovery during long-term mechanical support in advanced heart failure: insights into moving the field forward. J Heart Lung Transplant 35, 413-420, 2016.

FU X, SEGISER A, CARREL TP, TEVAERAI STHAEL HT, MOST H: Rat heterotopic heart transplantation model to investigate unloading-induced myocardial remodeling. Front Cardiovasc Med 3: 34, 2016.

GALIŇANES M, HEARSE DJ: Metabolic, functional and histologic characterization of the heterotopically transplanted rat heart when used as a model for the study of long-term recovery from global ischemia. $J$ Heart Lung Transplant 10: 79-91, 1991.

GALIŇANES M, ZHAI X, HEARSE DJ: The effect of load on atrophy, myosin isoform shifts and contractile function: studies in a novel rat heart transplant preparation. J Mol Cell Cardiol 27: 407-417, 1995.

GEENEN DL, MALHOTRA A, BUTTRICK PM, SCHEUER J: Ventricular pacing attenuates but does not reverse cardiac atrophy and an isomyosin shift in the rat heart. Am J Physiol 267: H2149-H2154, 1994.

CHAGGAR PS, WILIAMS SG, YONAN N, FILDES J, VENKATESWARAN R, SHAW SM: Myocardial recovery with mechanical circulatory support. Eur J Heart Fail 18: 1220-1227, 2016. 
HAMPL V, HERGET J, BÍBOVÁ J, BAŇASOVÁ A, HUSKOVÁ Z, VAŇOURKOVÁ Z, JÍCHOVÁ Š, KUJAL P, VERENEROVÁ Z, SADOWSKI J, ČERVENKA L: Intrapulmonary activation of the angiotensin-converting enzyme type 2/angiotensin 1-7/G-protein-coupled Mas receptor axis attenuates pulmonary hypertension in Ren-2 transgenic rats exposed to chronic hypoxia. Physiol Res 64: 25-38, 2015.

HANTON G, EDER V, ROCHEFORT G, BONNET P, HYVELIN JM: Echocardiography, a non-invasive method for the assessment of cardiac function and morphology in preclinical drug toxicology and safety pharmacology. Expert Opin Drug Metab Toxicol 4: 681-696, 2008.

HECKLE MR, FLATT DM, SUN Y, MANCARELLA S, MARION TN, GERLING IC, WEBER KT: Atrophied cardiomyocytes and their potential for rescue and recovery of ventricular function. Heart Fail Rev 21: 191-198, 2016.

IBRAHIM M, NADER A, YACOUB MH, TERRACCIANO C: Manipulation of sarcoplasmic reticulum $\mathrm{Ca}^{2+}$ release in heart failure through mechanical intervention. $J$ Physiol 593: 3253-3259, 2015.

ITO K, NAKAYAMA M, HASAN F, YAN X, SCHNEIDER MD, LORELL BH: Contractile reserve and calcium regulation are depressed in myocytes from chronically unloaded hearts. Circulation 107: 1176-1182, 2003.

KASSI M, HANNAWI B, TRACHTENBERG B: Recent advances in heart failure. Curr Opin Cardiol 33: 249-256, 2018.

KLEIN I, HONG S, SCHREIBR SS: Isovolumic loading prevents atrophy of the heterotopically transplanted rat heart. Circulation Res 69: 1421-1425, 1991.

KOLÁŘ F, MACNAUGHTON C, PAPOUŠEK F, KORECKY B: Systolic mechanical performance of heterotopically transplanted hearts in rats treated with cyclosporine. Cardiovasc Res 27: 1244-1247, 1993.

KOLÁŘ F, MACNAUGHTON C, PAPOUŠEK F, KORECKY B, RAKUSAN K: Changes in calcium handling in atrophic heterotopically isotransplanted rat hearts. Basic Res Cardiol 90: 475-481, 1995.

KOLÁŘ F, PAPOUŠEK F, MACNAUGHTON C, PELOUCH V, MILEROVÁ M, KORECKY B: Myocardial fibrosis and right ventricular function of heterotopically transplanted hearts in rats treated with cyclosporine. Mol Cell Biochem 164: 253-260, 1996.

KORECKÝ B, MASIKA M: Direct effect of increased hemodynamic load on cardiac mass. Cir Res 68: 1174-1178, 1991.

KORECKÝ B, RAKUŠAN K: Morphological and physiological aspects of cardiac atrophy. In: Perspectives in cardiovascular research. Vol. 7. Myocardial hypertrophy and failure. NL ALPERT (ed), Raven Press, New York, 1983, pp 293-309.

LEE LC, KASSAB GS, GUCCIONE JM: Mathematical modelling of cardiac growth and remodelling. WIREs Syst Biol Med 8: 211-226, 2016.

LIU Y, MAUREIRA P, GAUCHOTTE G, FALANGA A, MARIE V, OLIVER A, GROUBATCH F, GU C, PY M, TRAN N: Effect of chronic left ventricular unloading on myocardial remodeling: multimodal assessment of two heterotopic heart transplantation techniques. J Heart Lung Transplant 34: 882-889, 2014.

LOSSEF SV, LUTZ RJ, MUDORF J, BARTH KH: Comparison of mechanical deformation properties of metallic stents with use of stress-strain analysis. J Vasc Interv Radiol 5: 341-349, 1994.

MOAYEDI Y, ROSS HJ: Advances in heart failure: a review of biomarkers, emerging pharmacological therapies, durable mechanical support and telemonitoring. Clin Sci 131: 553-566, 2017.

NAVARATNARAJAH M, SIEDLECKA U, IBRAHIM M, VAN DOORN C, SOPPA G, GANDHI A, SHAH A, KUKADIA P, YACOUB MH, TERRACCIANO CM: Impact of combined clenbuterol and metoprolol therapy on reverse remodelling during mechanical unloading. PloS One 9: e92909, 2014.

ONO K, LINDSEY ES: Improved technique of heart transplantation in rats. J Thorac Cardiovasc Surg 57: 225-229, 1969.

PACHER P, NAGAYAMA T, MUKHOPADHYAY P, BATKAI S, KASS DA: Measurement of cardiac function using pressure-volume conductance catheter technique in mice and rats. Nat Protoc 3: 1422-1434, 2008.

POKORNÝ M, CERVENKA L, NETUKA I, PIRK J, KOŇAŘÍK M, MALÝ J: Ventricular assist devices in heart failure: how to support the heart but prevent atrophy? Physiol Res 63: 147-156, 2014. 
POKORNÝ M, MRÁZOVÁ I, MALÝ J, PIRK J, NETUKA I, VAŇOURKOVÁ Z, DOLEŽELOVÁ Š, ČERVENKOVÁ L, MAXOVÁ H, MELENOVSKÝ V, ŠOCHMAN J, SADOWSKI J, ČERVENKA L: Effects of increased myocardial tissue concentration of myristic, palmitic and palmitoleic acids on the course of cardiac atrophy of the failing heart unloaded by heterotopic transplantation. Physiol Res 67: 13-30, $2018 \mathrm{a}$.

POKORNÝ M, MRÁZOVÁ I, ŠOCHMAN J, MELENOVSKÝ V, MALÝ J, PIRK J, ČERVENKOVÁ L, SADOWSKI J, ČERMÁK Z, VOLENEC K, VACKOVÁ Š, MAXOVÁ H, ČERVENKA L, NETUKA I: Isovolumic loading of the failing heart by intraventricular placement of a spring expander attenuates cardiac atrophy after heterotopic heart transplantation. Biosci Rep 38: pii: BSR20180371. doi: 10.1042/BSR20180371, $2018 \mathrm{~b}$.

RITTER M, SU Z, XU S, SHELBY J, BARRY WH: Cardiac unloading alters contractility and calcium homeostasis in ventricular myocytes. J Mol Cell Cardiol 32: 577-584, 2000.

SOPPA GKR, LEE J, STAGG MA, SIEDLECKA U, YOUSSEF S, YACOUB MH, TERRACACIANO N: Prolonged mechanical unloading reduces myofilament sensitivity to calcium and sarcoplasmatic reticulum calcium uptake leading to contractile dysfunction. J Heart Lung Transplant 27: 882-889, 2008.

TAKASEYA T, ISHIMATSU M, TAYAMA E, NISHI A, AKASU T, AOYAGI S: Mechanical unloading improves intracellular $\mathrm{Ca}^{2+}$ regulation in rats with doxorubicin-induced cardiomyopathy. $J$ Am Coll Cardiol 44: 2239-2246, 2004.

WELSCH DC, DIPLA K, MCNULTY PH, MU A, OJAMAA KM, KLEIN I, HOUSER SR, MARGULIES KB: Preserved contractile function despite atrophic remodeling in unloaded rat hearts. Am J Physiol 281: H1131-H1136, 2001. 